\title{
Bałkański tygiel bezpieczeństwa kulturowego - radykalizacja w Bośni i Hercegowinie
}

\author{
„prochu ludzkiego, co mozolnie \\ prześlizguje się między Wschodem a Zachodem, \\ nie należąc do żadnego z nich, \\ a dostając cięgi od obu"
}

\section{Wprowadzenie}

Głównym tematem niniejszego artykułu jest charakterystyka podejścia badawczego, które pozwalałoby w adekwatny sposób ukazać zjawisko radykalizacji, oraz umieszczenie go w kontekście najnowszych dyskusji dotyczących metodologii badań w naukach społecznych, dziedziny bezpieczeństwa i obronności. Artykuł analizuje przyczyny badanego zjawiska, począwszy od krótkiego rysu historycznego po procesy radykalizacyjne, jakie mają miejsce w Bośni i Hercegowinie. Ponadto autorka zwraca uwagę, że niezbędne są dalsze badania w zakresie bezpieczeństwa kulturowego i identyfikacji zjawiska radykalizacji, a co za tym idzie i deradykalizacji, jako jednego z elementów szeroko rozumianego bezpieczeństwa.

Trudność tkwi przede wszystkim w tym, że nauki o bezpieczeństwie obejmują zróżnicowane aspekty, które w bardziej tradycyjnym ujęciu odpowiadają konglomeratowi różnych dyscyplin. Jednocześnie oczekuje się - m.in. ze względu na możliwość sformułowania rekomendacji na podstawie badań - że wynik będzie miał charakter spójny i jednolity. Tego rodzaju problem obserwuje się nie tylko w przypadku badań nad bezpieczeństwem, lecz - z uwagi na rosnącą złożoność podejść do przedmiotu badania - również w przypadku wielu dyscyplin w obrębie szeroko rozumianych badań społecznych. Odzwierciedleniem tej tendencji jest sze-

1 Według pisarza Ivo Andrić Bośnia i Hercegowina doświadczyła losu „człowieka lewantyńskiego". 
reg studiów nad „interdyscyplinarnością", „mutli-dyscyplinarnością” czy „trans-dyscyplinarnością” w badaniach nad bezpieczeństwem².

W niniejszym artykule autorka zawęża rozważania dotyczące podstaw metodologicznych badanych zjawisk do dziedziny nauk o bezpieczeństwie, ponieważ nauka ta umożliwia szerokie postrzeganie problematyki obrony oraz procesów radykalizacji i deradykalizacji, a stosowane w niej metody i techniki badawcze posiadają zastosowanie w pozostałych naukach społecznych.

Głównym celem niniejszych rozważań jest próba przedstawienia wagi problemu radykalizacji na Bałkanach, a w szczególności w Bośni i Hercegowinie. W celu zachowania jedności metodologicznej koniecznym jest przedstawienie rysu definicyjnego stosowanych pojęć, takich jak bezpieczeństwo kulturowe, radykalizacja oraz procesy deradykalizacyjne.

Wedle sformułowanej przeze mnie definicji, bezpieczeństwo kulturowe to zarówno obowiązek pomnażania dotychczasowego dorobku kulturalnego, jak i konieczność zapewnienia dostatecznej ochrony tożsamości narodowej, zdolność do obrony przed niepożądanym wpływem innych kultur oraz przeciwdziałanie zagrożeniom dla kultury, religii, języka. To jednocześnie podejmowanie przez państwo wszelkich działań celem ochrony dóbr kultury oraz wykorzystanie dorobku kulturalnego narodu.

Radykalizacja natomiast oznacza popadanie w skrajności, „stawanie się stanowczym i bezkompromisowym w poglądach i sposobach działania" również w sensie promowanego dyskursu oraz środków działania ${ }^{3}$. Radykalizacja może oznaczać w szerszym znaczeniu stan, w którym jednostka odrzuca świat i społeczeństwo, w którym żyje, i przekonuje się do nowej ideologii, w tym przypadku radykalnego islamu.

Deradykalizacja będzie w tym obszarze badawczym oznaczać przeciwdziałanie, odwracanie procesu radykalizacji. Jest to proces bardzo długi, z którym świat zachodni ma jednostkowe doświadczenia ${ }^{4}$.

2 Szerzej N.G. Fielding, Triangulation and Mixed Methods Designs Data Integration With New Research Technologies, New York 2012, s. 124-136.

3 T. Karpowicz, Stownik ortograficzny j. polskiego, Warszawa 2001.

4 Eksperyment we Francji skończył się niepowodzeniem. We wrześniu 2016 r. w małej wiosce Beaumont-en-Véron, liczącej poniżej 3000 mieszkańców, w regionie Loary, rozpoczęło działalność pierwsze eksperymentalne centrum deradykalizacji. Centrum Pontourny zostało zaprojektowane jako obóz dla osób będących w procesie radykalizacji. Projekt miał być pierwszym z 12 innych planowanych ośrodków, ale jego żywot okazał się dość krótkotrwały. Niecały 


\section{Bezpieczeństwo kulturowe - między religią a bezpieczeństwem}

„Obecnie radykałowie nie są w stanie obalać rządów ani wzniecać wojen” powiedział Dragan Simeunovic, ekspert do spraw terroryzmu i profesor nauk politycznych na uniwersytecie w Belgradzie w 2011 roku. Zdaniem badacza „Mogą jedynie przeprowadzać sporadyczne ataki terrorystyczne. Jeśli jednak będą rosnąć w siłę dzięki wsparciu finansowemu niektórych krajów muzułmańskich, możemy się spodziewać poważniejszych problemów na Bałkanach"5.

Radykalne ruchy fundamentalistyczne na Bałkanach są bezpośrednio powiązane z komórkami terrorystycznymi na całym świecie, a te z kolei są bardzo często pośrednio połączone z grupami mafijnymi, czy zorganizowanymi grupami przestępczymi o zasięgu międzynarodowym. Dlatego niedostrzeganie problemów związanych z radykalizacją na poziomie regionalnym ma negatywny wpływ na globalne bezpieczeństwo i staje się zagrożeniem bezpieczeństwa kulturowego. Dynamika tych problemów wzrasta z powodu globalizacji dzisiejszego świata oraz łatwości komunikowania i przemieszczania się.

Punktem wyjścia do prowadzonych badań było stwierdzenie, iż na wybranym obszarze Bałkanów, a w szczególności na terenie Bośni i Hercegowiny, dochodzi do znacznych procesów radykalizacyjnych, które są pochodną problemów społecznych oraz ekonomicznych. Co więcej, dotychczasowe relacje międzykulturowe przestały być motywem opisującym współczesny świat, a zmiany w obszarze współczesnych kultur i religii w badanych społeczeństwach są na tyle głębokie, iż należy je przeanalizować i zweryfikować przy wykorzystaniu odpowiednich metod badawczych. Dlatego też autorka niniejszego artykułu proponuje stosowanie terminu „bezpieczeństwo kulturowe” w odniesieniu do procesów, jakie postępują w obszarze radykalizacji na tych terenach.

rok później, 28 lipca, Ministerstwo Spraw Wewnętrznych wydało komunikat prasowy: „Eksperyment z otwartym centrum, działającym na zasadzie dobrowolności, okazał się nieskuteczny; rząd postanowił więc zakończyć eksperyment odbywający się w Pontourny - więcej na: https:// euroislam.pl/miala-byc-deradykalizacja-a-wyszlo/ [dostęp: 15.07.2017].

5 Zob. M. El Ghamari, Ekspansja Daesh na Bałkanach. Albania, Kosowo i Bośnia zagrożone, dostępne na: http://www.defence24.pl/290363,ekspansja-daesh-na-balkanach-albania-kosowo-i-bosnia-zagrozone [dostęp: 20.08.2017]. 
Po zakończeniu wojny w Bośni i Hercegowinie w 1995 roku na terenie tego kraju doszło do rozszerzenia się radykalnego islamu. Sprzyjały temu osiedlenie się w Bośni i Hercegowinie byłych bojowników, aktywność muzułmańskich organizacji charytatywnych i pomoc rozwojowa ze strony Arabii Saudyjskiej oraz Turcji. Konflikty, które wybuchły w 1999 roku w Kosowie i w 2001 roku w Macedonii, były kolejnymi czynnikami sprzyjającymi rozpowszechnieniu się przede wszystkim ideologii wahhabickiej. Grupy jej zwolenników pojawiły się w wielu miejscach, szczególnie na terenach wiejskich, zagrażając tradycyjnemu nurtowi umiarkowanego islamu. Ponadto, należy wyraźnie podkreślić, że wielu islamskich bojowników, którzy przybyli do Bośni, działało w poczuciu misji religijno-ideologicznej. Byli przekonani, że wojna domowa jest wynikiem ucisku i dyskryminacji bośniackich muzułmanów, którzy porzucili „prawdziwą wiarę” i dlatego muszą ponieść ofiarę krwi oraz powrócić do islamskich tradycji i korzeni, tj. salafizmu - muzułmańskiego ruchu religijnego i politycznego, postulującego odrodzenie islamu poprzez powrót do jego pierwotnych źródeł, „religii przodków”.

Obecnie radykalni muzułmanie starają się przejmować meczety w $\mathrm{BiH}$, Sandżaku, i Macedonii. Na terenie Kosowa i Albanii za pieniądze napływające z Arabii Saudyjskiej oraz coraz częściej z Turcji powstają nowe muzułmańskie centra i świątynie, a ich uczniowie mogą liczyć na stypendia i wyjazdy zagraniczne.

W dalszym ciągu w Bośni i Hercegowinie oraz innych krajach regionu znajduje się wiele osób podatnych na skrajnie radykalną ideologię. Niestety, sprzyjają temu bezrobocie, ubóstwo, problemy tożsamościowe i brak wiary w lepszą przyszłość dla młodego pokolenia 6 . Wszystkie te elementy związane są z brakiem poczucia bezpieczeństwa oraz istotą bezpieczeństwa kulturowego na obszarze Bałkanów. Bezpieczeństwo kulturowe związane z obawami o zachowanie tożsamości kulturowej staje się powoli odrębną kategorią bezpieczeństwa narodowego i międzynarodowego, wprowadzane jest do doktryny strategicznej oraz polityki kulturalnej państw. Choć nadal w oficjalnym nazewnictwie dominuje terminologia tradycyjna, to termin „bezpieczeństwo kulturowe” przebija się coraz czę-

6 Zob. K. Izak, Radykalny islam na Bałkanach źródłem konfliktów społecznych i terrorystycznego zagrożenia dla Europy, Warszawa 2013, s. 52. 
ściej jako skutek refleksji nad warunkami ochrony narodowej dziedzictwa kulturalnego w ich całościowym ujęciu. Staje się to przedmiotem współpracy prowadzonej w ramach ONZ, UNESCO i UE.

Pojęcie bezpieczeństwa kulturowego jest stosunkowo nowe, niemniej jednak historia potwierdza, że zjawisko to było doskonale znane w przeszłości. Zagrożenia dla kultury istniały od wieków (a nawet tysiącleci) i były skutkiem najazdów zbrojnych, podbojów kolonialnych (a nawet odkryć geograficznych) oraz spotkań kultur. Często doprowadzały do zniszczenia kultur wyższych, mających jednak słabsze zaplecze w postaci oręża zbrojnego ${ }^{7}$.

\section{Radykalizacja bośniackich i kosowskich muzułmanów}

Jedynie na przełomie 2013 i 2014 roku z Bośni i Hercegowiny zwerbowało się do Daesh (arab. ad-Dawla al-Islamiya fi al-Iraq wa al-Sham), tzw. Państwa Islamskiego, 156 mężczyzn i 36 kobiet. Kobiety zabrały ze sobą 25 dzieci. Do stycznia 2015 roku powróciło 48 mężczyzn i 3 kobiety, a 83 mężczyzn i 32 kobiety nadal pozostają prawdopodobnie w Syrii lub w Iraku. W sumie 26 (25 mężczyzn i 1 kobieta) obywateli BiH zostało zabitych. Większość zagranicznych bojowników z BiH początkowo mieszkała w kantonach Zenica-Doboj, Tuzla, Sarajewo oraz Una-Sana ${ }^{8}$. Co zatem ich motywowało?

Porozumienie z Dayton uznało bośniacki, chorwacki i serbski jako języki Bośni i Hercegowiny. BiH jest również sygnatariuszem Europejskiej Konwencji Praw Dziecka, która gwarantuje, że dziecko otrzymuje wykształcenie w swoim języku ojczystym. W etnicznie mieszanych prowincjach i w połączeniu z prawami dzieci do nauki w ich własnym języku, powszechne stało się zjawisko „dwóch szkół pod jednym dachem”, w których dzieci Bośniaków i Chorwatów uczęszczają na zajęcia oddzielnie, korzystając z tego samego budynku.

Próbując przezwyciężyć te silne podziały społeczne, które przełamują linie etniczno-religijne, władze państwowe wprowadziły ustawę ramową o szkolnictwie podstawowym i średnim w Bośni i Hercegowinie9 ${ }^{9}$ Wpro-

7 Zob. Z. Bauman, Kryzys państwa narodowego we wspótczesnej Europie, „Przegląd Zachodni" 1994, nr 4, s. 10-11.

8 Zob. http://www.oecd.org/countries/bosniaandherzegovina/36479798.pdf [dostęp: 30.06.2018].

9 Konstytucja BiH, http://www.servat.unibe.ch/icl/bk00000_html [dostęp: 10.06.2017]. 
wadziła ona wspólny podstawowy program nauczania, który miał na celu rozwinąć szeroką wiedzę merytoryczną i zapewnić absolwentom niezbędne umiejętności, by napędzać lokalną gospodarkę. Edukacja w publicznej lub prywatnej szkole jest obowiązkowa dla dzieci w przedziale wiekowym od 6 do 15 roku życia. Programy nauczania są szczególnie uwrażliwione na nauczanie religii oraz języka, wprowadzono cztery godziny lekcyjne na tematy religijne i narodowe oraz tak zwaną komunikację międzykulturową. Te szczątkowe próby radzenia sobie z podziałami etniczno-religijnym są w dalszym ciągu niewystarczające, a tylko pogłębiają zainteresowanie młodych uczniów tematami ekstremizmu i fundamentalizmu ${ }^{10}$.

Według danych z 25 kwietnia 2017 roku, struktura wyznaniowa w $\mathrm{BiH}$ prezentuje się następująco: 51\% mieszkańców wyznaje islam, 31\% prawosławie, $15 \%$ katolicyzm, $2 \%$ inne religie, a 1\% ludności stanowią ateiści i agnostycy ${ }^{11}$. Oficjalna edukacja religijna muzułmanów w BiH działa pod auspicjami Islamskiej Zajednica (IZ), co oznacza, że konstytucyjnie edukacja muzułmańska prowadzona przez IZ nawiązuje do tradycji hanafickiej. Zgodnie z artykułem IX i LXIX Konstytucji Islamskiej Wspólnoty Bośni i Hercegowiny, IZ jest odpowiedzialne za edukację muzułmańską. Zgodnie z artykułem XXVII członkowie IZ mają obowiązek prowadzenia muzułmańskiego wychowania i nauczania. Reis ul-Ulema (muzułmański przywódca religijny w Bośni i Hercegowinie) oraz Wielki Mufti BiH są odpowiedzialni za interpretację artykułu XLV Konstytucji Islamskiej Wspólnoty Bośni i Hercegowiny oraz za nauczanie muzułmańskie. Zaś w myśl artykułu XLVII, Mufti wyznacza radę składającą się z wielkich imamów i kodyfikuje zasady wyższych szkół muzułmańskich na terenie Bośni i Hercegowiny. Artykuł LII daje władzom możliwość powoływania, przekazywania i odrzucania kandydatów na imamów oraz podejmowania decyzji dotyczących rejestracji islamskich instytucji edukacyjnych. Wedle danych z 2016 roku, z ramienia IZ działa 1400 medres (szkół religijnych) gdzie kształci się około 60000 dzieci $^{12}$.

10 Zob. http://www.oecd.org/countries/bosniaandherzegovina/36479798.pdf [dostęp: 30.07.2017]

11 Zob. http://www.worldatlas.com/articles/religious-demographics-of-bosnia-and-herzegovina.html [dostęp: 15.06.2017].

12 Zob., http://www.islamskazajednica.ba/index.php [ dostęp: 29.09.2017]. 
Istnieją również dwie uczelnie wyższe: Univerzitet u Zenici i Univerzitet u Bihaću, które powstały jeszcze za czasów wojny, na przełomie 1992-1995 roku, przy finansowym wsparciu Arabii Saudyjskiej. Obecnie odgrywają znaczącą rolę w rozwoju wahhabizmu na terenie BiH. Większość studiujących tam osób wyjeżdża do Arabii Saudyjskiej na dalsze nauki religijne. Do głównego kanonu lektur należą publikacje autorstwa: Hassana Al-Banny, Sayyida Qutba i Jusufa al-Karadawiego, które można określić jako współczesną myśl społeczno-polityczną będącą podstawą ideologii Bractwa Muzułmańskiego.

Według różnych źródeł Bośnia i Hercegowina jest wykorzystywana przez międzynarodowe organizacje terrorystyczne głównie jako: islamski przyczółek w Europie, baza logistyczna, baza rekrutacyjna, miejsce odpoczynku i rekuperacji oraz kraj tranzytowy.

W ciągu ostatnich lat w Bośni i Hercegowinie miały miejsce działania antyterrorystyczne związane z międzynarodowym terroryzmem. Przykładem tych działań może być październik 2001 roku, gdy Bensayah Belkacem, Saber Lahmar, Ait Idir Mustafa, Boudallah Hadj, Boumedien Lakhdar i Necheld Mohammad zostali aresztowani pod zarzutem zaplanowania ataku terrorystycznego na ambasadę USA i ambasadę brytyjską w Sarajewie. Nie przedstawiono im żadnych zarzutów. Następnie 6 maja 2004 roku Departament Skarbu USA zamroził aktywa trzech organizacji charytatywnych podejrzanych o finansowanie terrorystycznej sieci Al-Kaidy. Władze zablokowały działalność muzułmańskich organizacji charytatywnych działających w Bośni i zmusiły trzy z nich do zamknięcia. W dniu 19 października 2005 roku bośniacki oddział antyterrorystyczny FMUP dokonał nalotu na dom w Ilidzie i aresztował Mirsada Bektaševicia i Kadara Cecura w związku z podejrzeniem o działalność terrorystyczną. Mirsad Bektašević to obywatel bośniacki, który jest posiadaczem szwedzkiego paszportu. Cecur jest obywatelem tureckim z duńskim paszportem. W dniu 12 grudnia 2006 roku na zlecenie prokuratury SIPA przeszukała kilka budynków w różnych lokalizacjach w Sarajewie. W jednym z przeszukiwanych budynków w dzielnicy Nedzarici mieściła się kuwejcka organizacja humanitarna.

Z pewnością należy stwierdzić, iż wahhabizm oraz salafizm zakorzeniły się w ciągu ostatnich 15 lat w tym kraju. Jednak jego charakteru oraz 
trajektorii rozwoju nie można porównywać do krajów europejskich takich jak Belgia, Niemcy, Francja czy Szwajcaria. Obecnie władze twierdzą, że w Bośni jest około 4000-4500 wahhabitów i około 3000 salafitów, co stanowi ułamek z 1,6 miliona muzułmanów w tym kraju. Ale rząd dodaje, że liczba zarówno wahabitów, jak i salafitów rośnie ${ }^{13}$.

Na podstawie przeprowadzonej analizy i licznych badań empirycznych można wyróżnić dwie tendencje w narracji na temat radykalizacji w Bośni. Jedna z nich ukazuje ten kraj jako przykład i wzór do naśladowania w kontekście idei europejskiego islamu. Społeczeństwo poszukujące powrotu do korzeni określa się jako umiarkowane, spokojne i elastyczne, które wprowadza w życie idee islamskiego reformizmu, łącząc tradycyjny islam z nowoczesną państwowością. Na potwierdzenie tej teorii wspomina się sunnicką tradycję sięgającą czasów osmańskich z silnym wpływem umiarkowanej szkoły prawniczej Hanafi i Szkoły Nauk Sufich. Do tego istotną rolę spełnia centralny autorytet duchowny wraz z dobrze zorganizowaną strukturą Ulame oraz muzułmańskich uczonych, które w 2017 roku obchodziły stulecie współistnienia z innymi religiami bez żadnych konfliktów. Ocenę tę wspiera również teza o zgodności legalnych instytucji islamskich z ideami państw świeckich: dobrze zorganizowany Ulema, medresami jako uznanymi religijnymi szkołami średnimi, fundacjami islamskimi np. Vakufs, i sądami szariackimi w zakresie prawa rodzinnego. Ponadto w $\mathrm{BiH}$ zorganizowano dodatkowe porozumienia strukturalne w obrębie kształcenia muzułmańskiego. Aby się zakwalifikować, przyszli imamowie musieli najpierw studiować w jednej z sześciu medres, a następnie na Wydziale Islamskim Uniwersytetu w Sarajewie. Ważna w tej analizie jest postać Mustafy Ćericia, który jest silnym przywódcą społeczności muzułmańskiej, cieszącym się ogromnym autorytetem w BiH.

Druga narracja opisuje BiH jako siedlisko terroryzmu i radyklanych muzułmanów. Artykuły o takiej tematyce są często rozpowszechniane w serbskich mediach oraz ośrodkach analiz bezpieczeństwa, co jak dobrze wiadomo, wynika jeszcze z zaszłości historycznych między tymi obszarami.

13 Wywiad z Vlado Azinovic, $12.2016 \mathrm{r}$. 
Fot. 1. Logo Wspólnoty Muzułmańskiej w BiH

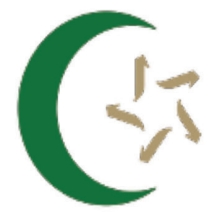

\section{ISLAMSKA ZAJEDNICA U BOSNI I HERCEGOVINI}

Źródło: http://www.islamskazajednica.ba/vijesti/aktuelno [dostęp: 20.07.2017].

Warto się jeszcze odnieść to tezy iż, wahhabizm nie jest rodzimym nurtem w BiH. Jest „obcą” ingerencja w bośniacką rzeczywistość, co z punktu widzenia tożsamości kulturowej jest niezwykle ważne. Obecnie liczbę wahhabitów w tym kraju ocenia się na 4,5 tys., a rzeszę ich sympatyków na około 60 tys. osób. Bośniaccy wahhabici prowadzą działalność sprzeczną z interesami Wspólnoty Muzułmańskiej, czyli tradycyjnego bałkańskiego i bardzo tolerancyjnego islamu. Wahhabici negują tradycyjne pojmowanie i praktykowanie islamu przez bośniackich muzułmanów. Otwarcie krytykują bośniacki islam za laicyzację - ilhad, odejście od źródeł i zaśmiecenie ich grzesznymi innowacjami - bida ${ }^{14}$. Wahabici szczególnie skutecznie rekrutują młodych „nawróconych” Bośniaków, określają muzułmanów wywodzących się z tradycji umiarkowanego islamu jako fałszywych muzułmanów, a nawet jako wrogów. Sposobem na rekrutację stają się wysokie stypendia naukowe, pomoc medyczna oraz finansowanie zagranicznych podróży, czy obozów religijnych w Arabii Saudyjskiej.

Wyzwaniem dla $\mathrm{BiH}$ staje się kontrola rozwoju ideologii wahhabickiej. O ile nie zostanie ona skutecznie zatrzymana i odwrócona przez miejscowe struktury muzułmańskie i wspólnoty religijne, może stanowić poważne wyzwanie dla $\mathrm{BiH}$ w jej wysiłkach zmierzających do utrzymania pluralistycznego społeczeństwa. Może także utrudnić i tak już skomplikowaną globalną wojnę z terroryzmem poprzez zapewnienie bezpieczniejszego środowiska dla powracających bojowników Daesh i ich rodzin, czy też tymczasowego lokum dla zmierzających na Zachód potencjalnych terrorystów.

Konflikty pomiędzy wahhabitami a innymi muzułmanami oraz próby zajęcia meczetów przez islamskich radykałów nasiliły się od końca 2006

14 Zob. http://www.islamskazajednica.ba/ [dostęp: 10.10.2017]. 
roku w całej Bośni i Hercegowinie, Sandżaku, Czarnogórze i Albanii. W miejscowości Gornja Maocza ${ }^{15}$, w której po wojnie domowej osiedliło się wielu arabskich mudżahedinów, budując zamkniętą społeczność, radykałowie utworzyli nielegalną szkołę podstawową z szariackim systemem nauczania. Pomimo stwierdzenia nieprawidłowości władze bośniackie nie podjęły stosownych działań w celu jej zlikwidowania ${ }^{16}$. W ostatnich latach w całej Bośni powstały organizacje charytatywne dotowane przez Arabię Saudyjską. Ich działalność sprowadziła się do pomocy w budowie 150 ultrakonserwatywnych meczetów. Ich obecność władze Sarajewa zauważyły po 11 września 2001 roku, co spowodowało zamknięcie 17 organizacji pozarządowych oraz 2 fundacji.

W dzielnicy Bascarsija (Sarajewo) wezwania na modlitwę rozbrzmiewają ponad kawiarniami i restauracjami, gdzie podaje się piwo czy wino i zaledwie kilka kobiet zasłania ciało oraz twarz. Jednak obserwując sytuację od 2009 roku, mogę stwierdzić, że ilość pojawiających się tradycyjnie ubranych kobiet i mężczyzn z roku na rok rośnie. To samo zjawisko jest zauważalne w meczetach, w których niegdyś na czas modlitw nie pojawiała się znaczna liczba wiernych.

Co ciekawe, z badań empirycznych wynika, że zwiększa się również liczba małżeństw bośniacko-arabskich. Jest to związane szczególnie z działalnością organizacji matrymonialnych w Bośni, które oferują swoje usługi zainteresowanym mężczyznom z państw Zatoki (szczególnie z Kataru). Zwiększyła się również liczba lotów do katarskiej stolicy, Dohy, z bośniackiego Sarajewa. Poza zwykłą turystyką szczególnego znaczenia nabiera właśnie turystyka matrymonialna.

Na podstawie przeprowadzonych badań empirycznych wyodrębniłam obszary, które są szczególnie ważne dla wspólnoty wahhabickiej. Są nimi miasteczka Konjic, Jablanica, Mostar (coraz mniej na przełomie 2009-2017) znajdujące się nad Neretwą, oraz: Buca Potok, Gornja Maoca, Boczinja, Hadżici, Ilidża, Maocza, Osmacza, Sanski Most, Sarajewo, Sutjeska, Travnik, Tuzla, Zenica, Visoko.

15 K. Izak, Radykalny islam na Bałkanach źródtem konfliktów społecznych i terrorystycznego zagrożenia dla Europy, 2013, s. 52.

16 Zob., http://mostarski.ba/medzlis-iz-mostar-saopstenje-za-javnost-o-prikupljanju-sadekati-l-fitra-u-mostaru/ [dostęp: 3.08.2017]. 
Ponadto bośniaccy wahhabici są kontrolowani przez Muhameda Fadila Porča, który jest imamem meczetu Al-Tawhid w Wiedniu i koordynatorem organizacji Młodzieży Islamskiej Europy. M.F. Porca jest znany ze swoich radykalnych poglądów i wysyłania bojowników do Syrii i Iraku. Razem z nim działają Safet Kuduzović i Nusret Imamović, którzy używają salaficko - wahhabickiego portalu misyjnego Studio-Din (www.studiodin.com ${ }^{17}$. Ciekawą organizacją jest także działająca w Bośni Kelimetul Haqq, również z siedzibą w Wiedniu, pod kierownictwem Nedžada Bałkanana, znanego w sieci jako Abu Muhammad, który jest imamem meczetu Al-Sahaba w Wiedniu.

Fot. 2. Centrum Kulturowe Fahd, prowadzone przez Arabię Saudyjską w Sarajewie

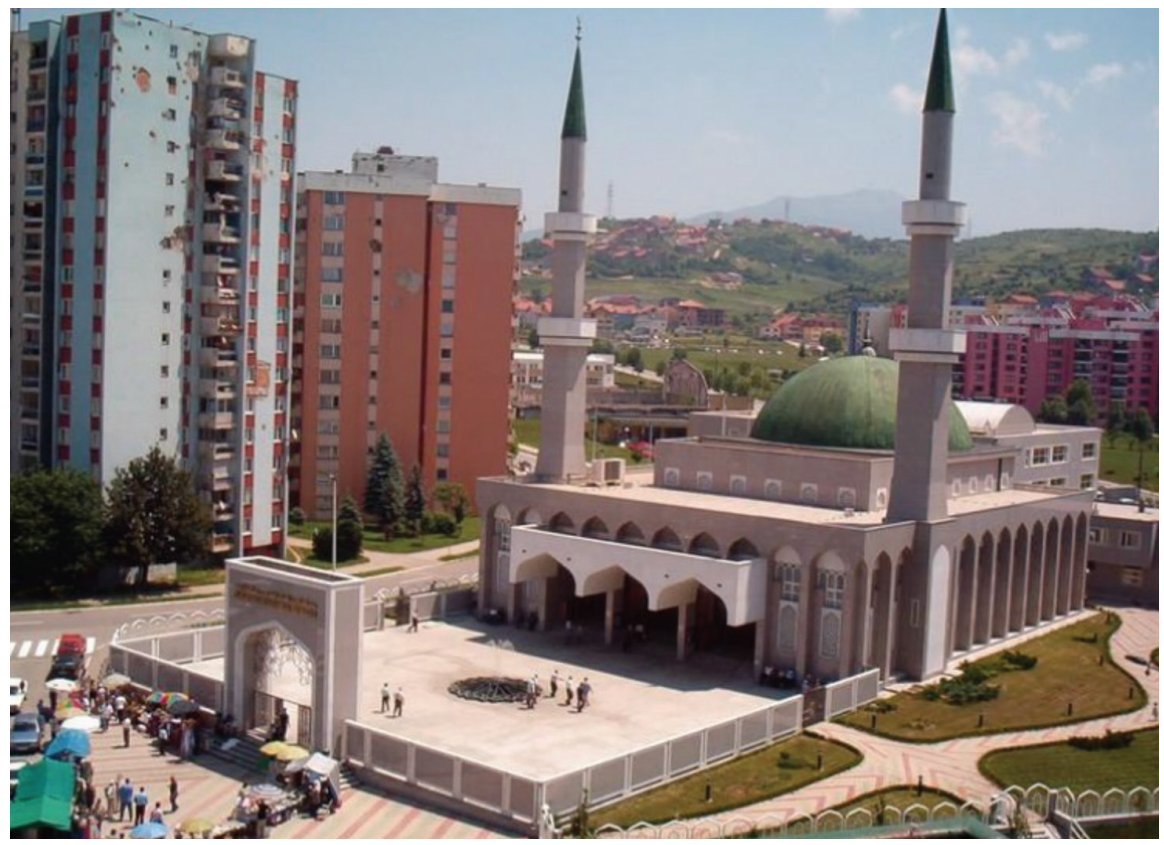

Źródło: http://www.kf-cc.ba/ [źródło; 27.08.2017]

Co najmniej 10\% bośniackich meczetów i fizycznych struktur religijnych wchodzących w skład IZ Waqf otrzymało wsparcie od Arabii Sau-

17 Portal udostępnia swoje kazania na kanałach YouTube, np. https://www.youtube.com/ watch?v=g2d4qJua_g4 [dostep: 20.10.2017]. 
dyjskiej, chociaż rząd saudyjski podaje wartość $24 \%$ sumy sprzed wojny 1992-1995. Wakf oznacza w prawie muzułmańskim zapis pieniężny na cele religijne, charytatywne lub publiczne, stanowiący zinstytucjonalizowaną formę przekazywania nakazanej przez islam jałmużny, czyli zakatu. W Sarajewie znajduje się Centrum Kulturalne Króla Fahda dla 5000 osób, Kralj Fahd Džamija ${ }^{18}$. W opinii badanych respondentów oraz osób na stałe mieszkających w Sarajewie, obiekt ten jest wykorzystywany do radykalizowania bośniackich muzułmanów. Jeden z moich rozmówców nazwał je "gniazdem prania mózgów przez wahhabitów". Co więcej, Rada Powierników Centrum Kulturalnego Króla Fahda planuje w najbliższych latach wybudować stałe centrum kulturalne w sercu Sarajewa, które byłoby koordynowane przez ambasadę Arabii Saudyjskiej.

Z miejscowości Gornja Moa zrekrutowało się najwięcej bojowników, którzy udali się na Bliski Wschód, by walczyć w szeregach Daesh. Szacuje się, że około 250 Bośniaków od 2012 roku walczyło w Syrii lub w Iraku. Stanowi to największy odsetek zwerbowanej ludności spośród wszystkich krajów europejskich, za wyjątkiem Belgii. Około 45 zostało zabitych, a około 50 wróciło do domu ${ }^{19}$.

Bośnia może pozostać atrakcyjna dla globalnego terroryzmu oraz ruchów ekstremistycznych skłonnych do radykalizacji społeczeństwa również z powodu łatwego dostępu do broni, materiałów wybuchowych, endemicznej korupcji, wpływowych sieci zorganizowanej przestępczości, braku egzekwowanego prawa i porządku, porowatej kontroli granicznej i obecności niektórych radykalnych społeczności, które mogłyby wykorzystać $\mathrm{BiH}$ jako bazę logistyczną i rekrutacyjną, strefę odpoczynku i rekonwalescencji lub kraj tranzytowy. Pomimo faktu, że potencjalne zagrożenie terroryzmem w BiH można uznać za całkowicie związane z szerzeniem się ekstremistycznych idei religijnych w kraju, to zauważalny jest fakt, że grupy ekstremistyczne w BiH mają zdolność do promowania swojej ideologii, rekrutowania większej liczby personelu, rozwijania organizacji i struktury logistycznej wewnątrz kraju. Niemniej jednak organizacjom tym nadal brak poparcia ze strony populacji BiH jako całości, a także części reforma-

18 Zob., http://en.themwl.org/about-mwl [dostęp: 10.10.2017].

19 Zob., http://www.telegraph.co.uk/news/2016/04/30/muslim-radicals-in-mountain-villages-spark-fears-in-bosnia/ [dostęp: 20.07.2017]. 
torów salafickich, którzy chcą zdystansować się od bardziej radykalnego skrzydła ruchu wahhabickiego. Bardziej radykalne elementy społeczności salafickiej są w dużym stopniu odizolowane przez resztę muzułmańskiego społeczeństwa $\mathrm{BiH}$.

Fot. 3. Zdjęcie wykonane przed wjazdem do miasteczka Gornja Maoca w Bośni i Hercegowinie w 2014 roku

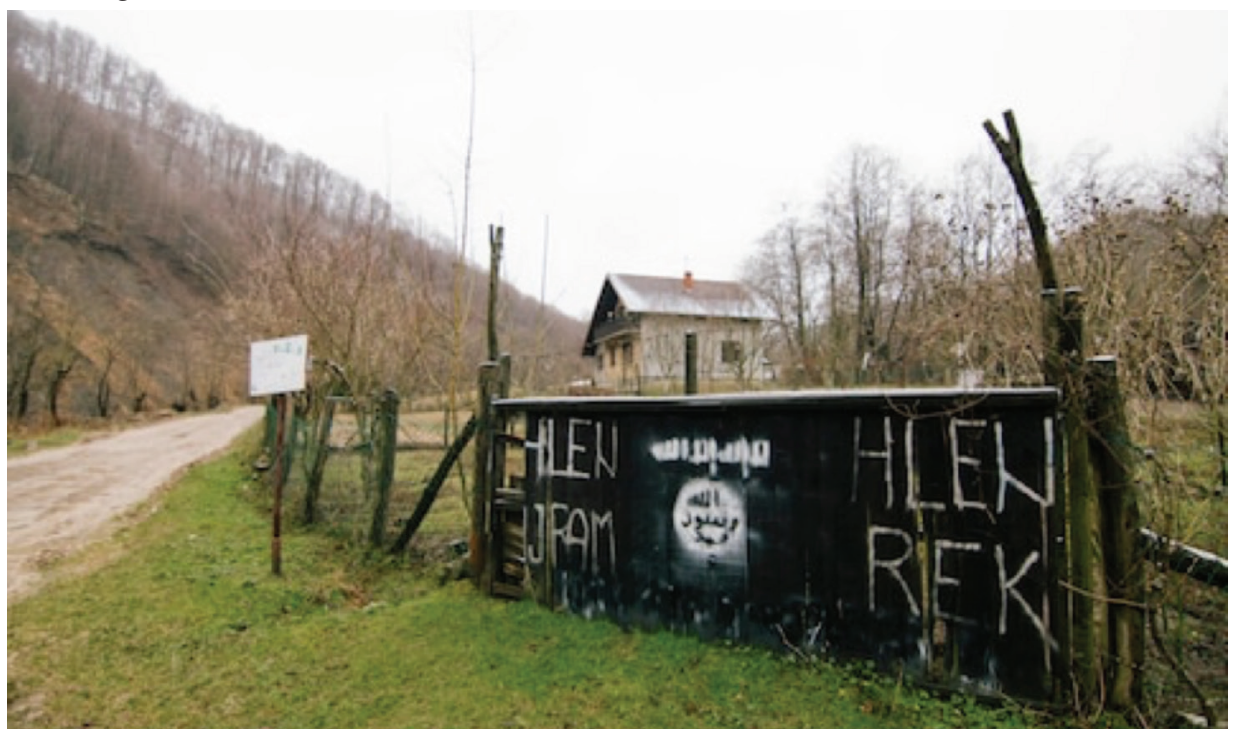

Źródło: Materiały prywatne.

Te tendencje są widoczne nie tylko w Bośni, ale i w Kosowie. Obawy przed radykalizacją kładą się cieniem na całych Bałkanach, które nadal są osłabione przejściem z systemu komunistycznego do kapitalistycznego oraz ostatnim kryzysem gospodarczym. Religia nigdy nie odgrywała w Kosowie ważnej roli, jednak problemy ekonomiczne, niemalże 45\% stopa bezrobocia w połączeniu z narastającą biedą i korupcją, skłaniają wielu ludzi do szukania innych metod radzenia sobie z powyższymi kwestiami głównie w meczetach. Władze Kosowa były kompletnie zaskoczone, kiedy planowany przez Ministerstwo Edukacji zakaz noszenia chust w szkołach publicznych został oprotestowany przez tysięczny tłum w 2016 roku.

Na podstawie prowadzonych badań i przy pomocy lokalnych źródeł, możliwe było odtworzenie trendów w podróżach z BiH do Syrii i Iraku 
w okresie od 2012 roku do końca 2015 roku. Na podstawie zarejestrowanych dat wyjazdu i wjazdu uznano że 176 mężczyzn miało udać się do Syrii: 15 osób uczyniło to w 2012 roku, 114 w 2013 i 19 w 2014 roku. W ośmiu przypadkach niemożliwe było ustalenie daty wyjazdu i powrotu danej osoby. Niektórzy z nich podróżowali kilkakrotnie, szczególnie między wiosną a wczesną jesienią 2013 roku, kiedy wrócili z Syrii na kilka tygodni, a następnie wyjechali ponownie do tego kraju. W tym czasie wielu z nich towarzyszyły żony i, dość często, dzieci. Niektórzy z tych mężczyzn byli już w związkach małżeńskich, ale niektórzy pobierali się podczas krótkiej przerwy w Bośni i Hercegowinie, głównie ze względu na korzyści oferowane zagranicznym bojownikom, którzy przybywają wraz z rodzinami do Syrii.

Wielu polityków i ekspertów pochodzących z tych krajów wyraża opinię, że radykalny islam w coraz większym stopniu zagraża stabilizacji na Bałkanach. Wahhabickie wspólnoty są agresywne wobec mieszkańców miejscowości, w których żyją i nie stronią od stosowania wobec nich przemocy. Co więcej, w imię „deradykalizacji” w krajach bałkańskich władze starają się prowadzić dialog z radykałami, monitorują obiekty sakralne i prowadzą zajęcia informujące o skutkach włączenia się np. do działań terrorystycznych. Przykładowo władze Kosowa wykorzystały byłych bojowników Daesh i w ramach ich deradykalizacji prowadzą obecnie serię wykładów dla uczniów i studentów, podczas których opowiadają swoją tragiczną historię. Warto zaznaczyć, że każdy kraj w badanym regionie cechuje się odmiennym charakterem samej radykalizacji, dlatego mechanizmy odwracania tego procesu muszą być odmienne i przede wszystkim musi występować wola do prowadzenia skoordynowanych działań.

\section{Rekruci i bojownicy Daesh}

Propaganda Daesh w bardzo przemyślany sposób trafia do młodzieży, wykorzystując ich problemy, wrażliwość, zagubienie i brak krytycznego myślenia. Wobec tych, do których trafia, stosuje werbunek opierający się na wartościach i upadku współczesnej moralności; islamscy terroryści posługują się retoryką religijną. Wmawiają swoim nowym członkom, że są posłańcami i jako męczennicy będą cieszyć się wystawnym życiem pozagrobowym. 
Dla mieszkańców Bałkanów, w tym Bośniaków, Kosowarów, Albańczyków, utworzony przez Daesh kalifat jest niezmiernie atrakcyjny, daje ułudę atrakcyjnej podróży, w którą ludzie chcą się udać. Bojownik, z którym udało mi się rozmawiać w czerwcu 2017 roku, został zwerbowany w jeszcze inny sposób. Było nim stowarzyszenie/fundacja pomagająca ofiarom wojny w Syrii. Po zebraniu datków jego misją miało być dostarczenie przesyłki pod pozorem pomocy humanitarnej. Na miejscu okazało się, że nie ma innej drogi - zostaje albo śmierć jego bliskich, albo przyłączenie się do Daesh i pełnienie funkcji kuriera. Niektórzy ludzie traktują przyłączenie się do Daesh jako rodzaj misji oraz wspaniałej przygody. Bardzo często porzucają wygodny styl życia, który oferuje im kraj rodzinny i wybierają walkę u boku bojowników z Państwa Islamskiego, wierząc, że działają w dobrej wierze, że służą ludzkości i wypełniają misję.

Jak pokazuje doświadczenie lat 2012-2016, metody rekrutacji okazały się skuteczne. Do najważniejszych powodów radykalizacji osób z BiH oraz chęci przyłączenia się do Daesh należą:

- wszechogarniająca nuda,

- chęć spełnienia się w walce,

- chęć wzięcia udziału w czymś „wielkim”,

- brak perspektyw,

- czynnik ekonomiczny - brak pracy,

- radykalizacja poglądów,

- uleganie wpływom imamów popierających konflikt w Syrii i Iraku,

- młodzi mężczyźni, którzy stanowią najwięcej ochotników, walkę w oddziałach PI traktują jako przygodę,

- jednostki wyalienowane ze społeczeństwa w dżihadzie odnajdują sens swego życia.

Średnia wieku mężczyzn z Bośni i Hercegowiny na syryjskich polach bitewnych wynosiła około 31-32 lat. Najmłodszy mężczyzna miał 18 lat, a najstarszy 75 lat. Ponadto istnieją dwie wyraźne grupy pokoleniowe, które przybyły z Bośni i Hercegowiny do Syrii: pierwsza obejmuje ludzi w wieku około 40 lat, często z doświadczeniem z wojny 1992-1995; a druga obejmuje młodszych mężczyzn, nastolatków lub osoby nieco starsze. Grupy te różniły się pod względem powodów, dla jakich udały się na wojnę. 
Kobiety z BiH zaczęły podróżować do Syrii w 2013 roku w ramach tendencji wyjazdów rodzinnych. Łącznie w 2014 roku wyjechało 10 kobiet, a w 2015 roku - 24. Jedynie w kilku odosobnionych przypadkach kobiety przybyły do Syrii bez swoich mężów, braci i ojców; ale wtedy spotkały się z presją, by albo wyjść za mąż wbrew swojej woli, albo mieć opiekunów. Średni wiek kobiet wyjeżdżających z Bośni i Hercegowiny wynosi 27 lat. W chwili przybycia najmłodsza kobieta miała 18 lat, a najstarsza 55. Istnieje jeden przypadek, w którym kobieta z Bośni i Hercegowiny została uzbrojona, jako członek formacji policyjnej ISIL. Według jej zeznania, brała udział w aktach przemocy, uczestnicząc w egzekucjach innych kobiet z tej samej formacji, oskarżonych o szpiegostwo, a następnie rozstrzeliwanych. Pozostałe kobiety przybyłe z BiH pełniły funkcje „rodzinne”.

Według wszelkich analiz dotyczących pochodzenia islamskich ekstremistów z Daesh wynika jednoznacznie, że oprócz krajów arabskich dużą część bojowników stanowią muzułmanie z Bośni, Kosowa oraz Albanii. Wynika z tego, że wydarzenia na Bliskim Wschodzie stanowią niebezpieczeństwo dla Europy, a szczególnie Europy Zachodniej, gdzie zamieszkuje znaczna diaspora z krajów arabskich. Ekstremiści zamieszkujący Europę mogą wykonywać usługi wywiadowcze dla różnego rodzaju organizacji o charakterze terrorystycznym. Fakt, że tak wielu muzułmanów zamieszkujących nasz kontynent okazało się bojownikami dżihadu wskazuje, że poziom bezpieczeństwa państw europejskich pozostawia dużo do życzenia. $Z$ drugiej jednak strony, nie ma prostego rozwiązania tego problemu. Prawdopodobnie nie grozi nam powstanie kolejnego państwa islamskiego gdzieś na terenie Europy, gdyż warunki są tu odmienne niż w Iraku lub Syrii. Niemniej jednak przy okazji kolejnego kryzysu w tej części świata okazało się, że ma on realne przełożenie na poziom bezpieczeństwa Europy.

\section{Zakończenie}

Bojownicy powracający z Syrii i Iraku - zaprawieni w walce, wykwalifikowani w obsłudze broni i materiałów wybuchowych oraz ideologicznie zradykalizowani - stanowią bezpośrednie zagrożenie nie tylko dla bezpieczeństwa w Bośni i Hercegowinie, ale także w regionie i poza nim. Po powrocie mogą należeć do istniejących sieci zradykalizowanych osób lub 
zakładać nowe. Dodatkowo ich powrót może mieć długotrwały wpływ na społeczeństwo $\mathrm{BiH}$, ponieważ „byli” bojownicy mogą rzucić wyzwanie istniejącemu przywództwu w swoich społecznościach lub stać się wzorem do naśladowania dla młodego radykalizującego się pokolenia. Konieczne jest zatem monitorowanie, analizowanie i raportowanie tego zjawiska, a także opracowanie skutecznej kontr-narracji i różnych strategii interwencji celem deradykalizacji.

Współczesny świat podlega dwóm, niejako sprzecznym wobec siebie procesom. Z jednej strony mamy zjawisko wszechogarniającej globalizacji, a z drugiej - na obszarach do niedawna zniewolonych komunizmem i przeżywających euforię z odzyskanej suwerenności - procesy odbudowy systemu tradycyjnych wartości. Mimo że procesy te oddziałują w różnych kierunkach, ich skutki w odniesieniu do sfery kultury bywają podobne, a niekiedy nakładają się. Globalizacja, poprzez rozpowszechnianie wzorów kultury masowej, powoduje erozję dotychczasowych, do pewnego stopnia homogenicznych, symboli i wzorców kulturowych. Coraz trudniej jest w tych warunkach określić własną tożsamość poprzez odwołanie się do konkretnego obywatelstwa czy też zawodu. Wzmaga się więc pokusa, aby czynić to na podstawie przynależności do wspólnoty kulturowej, takiej jak: grupa etniczna czy religijna, płeć czy sposób zachowania się. Zaczynają się liczyć także symbole (flagi, krzyże, półksiężyce, nakrycia głowy, stroje itp.) i zaczyna się je ostentacyjnie manifestować. W krajach postkomunistycznych, które też ogarnia globalizacja, te demonstracyjne gesty są dodatkowo wzmocnione chęcią odreagowania czasów, gdy używanie symboli, manifestowanie religijności, etniczności czy kulturowej odrębności nie było mile widziane. Oczywiście to nie wszystkie powody takich postaw, dodajmy do tego procesy integracji politycznej i gospodarczej, powstawanie struktur o kompetencjach ponadnarodowych, a także uniwersalizację wielu instytucji i procesów kulturalnych, w tym na przykład praw człowieka i mniejszości narodowych.

Wszystkie te procesy sprawiają, że coraz bardziej liczy się kwestia tożsamości. Nowe wyzwania globalne, gospodarcze, społeczne i kulturowe stawiają przed jednostkami, grupami społecznymi, narodami i państwami problem potwierdzenia na nowo swojej tożsamości. Ma to wymiar zarówno lokalny, regionalny, narodowo-państwowy, jak i międzynarodowy. 
Pojawiają się kwestie budowania i przypisywania tożsamości wspólnotom i organizacjom noszącym cechy transnarodowe, wspólnotom religijnym etc. Jedynie na podstawie analizy zachodzących procesów oraz poprzez prowadzenie długofalowych badań empirycznych będzie można zaproponować konkretne rozwiązania deradykalizacyjne. Obecnie, działania deradykalizacyjne mogą mieć jedynie formę eksperymentu na żywym organizmie, z nieprzewidzianym efektem.

\section{Bibliografia}

Bauman Z., „Kryzys państwa narodowego we wspótczesnej Europie”, „Przegląd Zachodni" 1994, nr 4.

Izak K., Radykalny islam na Bałkanach źródłem konfliktów społecznych i terrorystycznego zagrożenia dla Europy, Warszawa 2013.

Fielding N.G., Triangulation and Mixed Methods Designs Data Integration With New Research Technologies, New York 2012.

Karpowicz T., Stownik ortograficzny j. polskiego, Warszawa 2001.

\section{Źródla internetowe}

El Ghamari M., Ekspansja Daesh na Bałkanach. Albania, Kosowo i Bośnia zagrożone, http://www.defence24.pl/290363,ekspansja-daesh-na-balkanach-albania-kosowo-i-bosnia-zagrozone.

http://www.oecd.org/countries/bosniaandherzegovina/36479798.

http://www.oecd.org/countries/bosniaandherzegovina/36479798.pdf.

http://www.worldatlas.com/articles/religious-demographics-of-bosnia-and-herzegovina.html.

http://www.islamskazajednica.ba/index.php. http://mostarski.ba/medzlis-iz-mostar-saopstenje-za-javnost-o-prikupljanju-sadekati-l-fitra-u-mostaru/.

https://www.youtube.com/watch?v=g2d4qJua_g4.

http://en.themwl.org/about-mwl.

http://www.telegraph.co.uk/news/2016/04/30/muslim-radicals-in-mountain-villages-spark-fears-in-bosnia/.

Konstytucja BiH, http://www.servat.unibe.ch/icl/bk00000_.html. 


\section{Balkan melting pot of cultural security - radicalization in Bosnia and Hercegovina}

\section{Summary}

After the end of the war in Bosnia and Herzegovina in 1995, radical Islam spread in the country. The process of radicalization was influenced by the activity of Islamic charities and development assistance from Saudi Arabia and the settlement of former Arab fighters in Bosnia and Herzegovina.

The article aims to argue the importance of the problem of cultural security and radicalization in the Balkans, and in particular in Bosnia and Herzegovina.

In Bosnia and Herzegovina, the authorities try to implement educational policy that tackles multiculturalism and religion, as well as to open a dialogue with radicals who have become a threat to the majority of residents. Nonetheless, there are many people in Bosnia and Herzegovina who are vulnerable to radical ideology, which in extreme cases resulted in them taking a journey to Syria and Iraq and joining the so-called Islamic State. The reasons behind this decision were, among others: unemployment, poverty and lack of faith in a better future for the young generation.

Keywords: Balkans peninsula, security, radicalization, Bosnia and Herzegovina

\section{Бамканский пмавимьный котем кумьтурной безопасности - радикализация в Боснии и Герцеговине}

\section{Резюме}

После окончания войны в Боснии и Герцеговине в 1995 году в стране распространился радикальный ислам. На это повлияла деятельность исламских благотворительных организаций и помощь в целях развития из Саудовской Аравии и поселение бывших арабских боевиков в Боснии и Герцеговине. ГАавная цель этих соображений - попытаться преАставить важность проблемы культурной безопасности и радикализации на Балканах, и в частности в Боснии и Герцеговина. В Боснии и Герцеговине власти пытаются вести образование, связанное с мультикультурализмом и религией, и Ааже Аиалог с радикалами, которые стали угрозой Аля большинства жителей. Несмотря на это, в Боснии и Герцеговине очень много Аюдей, которые уязвимы переА крайне радикальной идеологией, что в крайних случаях привело к поезАке в Сирию и Ирак и присоединению к Ааэшу - так называемому исламскому 
государству. Этому способствовали, среди прочего, безработица, нищета и отсутствие веры в кучшие перспективы молодого поколения.

Кмючевые слова: Балканы, безопасность, радикализация, Босния и Герцеговина

\author{
dr Magdalena El Ghamari \\ Centrum Badań nad Ryzykami Społecznymi i Gospodarczymi \\ Pracownia Bezpieczeństwa Kulturowego \\ Collegium Civitas \\ Pałac Kultury i Nauki \\ plac Defilad 1, XII piętro \\ 00-901 Warszawa
}

